\title{
Regulation of Partial Nitritation in Constructed Rapid Infiltration System and Analysis of Microbial Community Structure
}

\author{
Jiao Chen ${ }^{1-3}$, Yixin Lu ${ }^{1,3}$, Zhiqiang Ouyang ${ }^{1}$, Jianqiang Zhang ${ }^{3 *}$ \\ ${ }^{1}$ College of Architectural and Environmental Engineering, Chengdu Technological University, Chengdu, China \\ ${ }^{2}$ Center of Big Data for Smart Environmental Protection, Chengdu Technological University, Chengdu, China \\ ${ }^{3}$ Faculty of Geosciences and Environmental Engineering, Southwest Jiaotong University, Chengdu, China
}

Received: 20 August 2018

Accepted: 21 November 2018

\begin{abstract}
Partial nitritation (PN) and the anaerobic ammonium oxidation (ANAMMOX) process provides a novel method to solve the problem of low TN removal efficiency in a constructed rapid infiltration (CRI) system, and PN is the prerequisite to realize the process. In this study, the feasibility of achieving $\mathrm{PN}$ in a CRI system by synergistic regulation of free chlorine, filter height and influent $\mathrm{pH}$ was investigated. The characteristics of microbial community structure during the stable operation of the PN process were also discussed. The results showed that after adding $3 \mathrm{mg} / \mathrm{L}$ of free chlorine continuously for 23 days, adjusting the effluent filter height to $75 \mathrm{~cm}$ and the influent $\mathrm{pH}$ to $8.2 \sim 8.5$, the PN process successfully started with the $\mathrm{NO}_{2}^{-}-\mathrm{N}$ accumulation rate staying stable at about $90 \%$ and effluent $\mathrm{NO}_{2}^{-}-\mathrm{N} / \mathrm{NH}_{4}{ }^{+}-\mathrm{N}$ ratio between 1.23 and 1.35 , thus providing suitable influent conditions for the subsequent ANAMMOX. Based on 16S rRNA high-throughput sequencing, a total of 41 phyla, 144 classes and 310 genera were detected from the stable running PN-CRI system. The detected ammonia-oxidizing microorganisms mainly included Nitrosomonas, Nitrosovibrio and Candidatus Nitrososphaera; while only Nitrospira was detected in nitrite-oxidizing bacteria genera with its relative abundance at only $6.7 \sim 10.0 \%$ of the total abundance of ammonia-oxidizing microorganisms. This indicated that the synergistic regulation strategy could selectively eliminate nitrite-oxidizing bacteria, thus creating favorable conditions for the occurrence of PN. These findings could provide a theoretical basis and scientific reference for efficient and economical nitrogen removal in a CRI system.
\end{abstract}

Keywords: synergistic regulation, CRI system; partial nitritation, microbial community structure

*e-mail: zhjiqicn@swjtu.cn 


\section{Introduction}

Constructed rapid infiltration (CRI) is a new ecological wastewater treatment technology developed in recent years with the advantages of less construction investment, simple operation and low operating cost [1]. It uses material such as natural river sand, zeolite sand and marble sand with good percolation performance as filter media, and the hydraulic loading is higher than the traditional soil infiltration and constructed wetland system, which made it particularly suitable for the treatment of wastewater in small towns or rural areas that are not yet covered by a municipal pipe network $[2,3]$. However, the concentration of organic matter in wastewater decreased gradually with the increase of filter depth, and the $\mathrm{C} / \mathrm{N}$ ratio of wastewater entering the lower part of the CRI system was low. As a result, the total nitrogen (TN) of the CRI system could not be removed effectively due to the lack of carbon sources for the denitrification process. The TN removal rate of the CRI system was only $10 \sim 30 \%$ [4], which limited the further application and promotion of the technology. Therefore, it is of great scientific and practical significance to explore an efficient and economical nitrogen removal method for a CRI system.

Recently, partial nitritation (PN) and the anaerobic ammonium oxidation (ANAMMOX) process has been considered to be the most efficient and economical biological nitrogen removal method [5]. Compared with conventional nitrification and denitrification, the PN-ANAMMOX process can reduce oxygen consumption by $62.5 \%$ without additional carbon sources. The process not only saves cost, but also avoids secondary pollution, and can effectively solve the problem of high energy consumption and insufficient carbon source in traditional biological nitrogen removal, which made it a focus of low $\mathrm{C} / \mathrm{N}$ ratio wastewater treatment research [6, 7]. ANAMMOX is a biological oxidation process that uses $\mathrm{NH}_{4}^{+} \mathrm{-N}$ to replace the organic carbon source as an electron donor and $\mathrm{NO}_{2}^{-}-\mathrm{N}$ to replace $\mathrm{O}_{2}$ as an electron acceptor to translate them into $\mathrm{N}_{2}$ in an anoxic or anaerobic environment [8]. The stoichiometric equation for the process is as follows:

$$
\begin{gathered}
\mathrm{NH}_{4}^{+}+1.32 \mathrm{NO}_{2}^{-}+0.066 \mathrm{HCO}_{3}^{-}+0.13 \mathrm{H}^{+} \\
\rightarrow 1.02 \mathrm{~N}_{2}+0.26 \mathrm{NO}_{3}^{-}+ \\
0.066 \mathrm{CH}_{2} \mathrm{O}_{0.15} \mathrm{~N}_{0.15}+2.03 \mathrm{H}_{2} \mathrm{O}
\end{gathered}
$$

According to Equation (1), the theoretical influent $\mathrm{NO}_{2}{ }^{-}-\mathrm{N} / \mathrm{NH}_{4}^{+}-\mathrm{N}$ ratio of ANAMMOX is 1.32:1 [9]. The efficient removal of nitrogen pollutants can be achieved when the influent meets the condition. However, the concentration of $\mathrm{NO}_{2}^{-}-\mathrm{N}$ in general domestic sewage is low, which cannot meet the influent requirement of ANAMMOX [10]. Thus, control of the nitrification reaction stop at the partial nitritation stage, that is, control $50 \sim 60 \%$ of $\mathrm{NH}_{4}^{+}-\mathrm{N}$ oxidized to $\mathrm{NO}_{2}^{-}-\mathrm{N}$, and let the concentration ratio of $\mathrm{NO}_{2}^{-}-\mathrm{N}$ and $\mathrm{NH}_{4}^{+}-\mathrm{N}$ in effluent be close to 1.32 , which is the prerequisite and necessary condition for the successful realization of efficient nitrogen removal by ANAMMOX [11].

Previous studies have investigated a series of regulation methods for the start-up of partial nitritation. Ge et al. [12] studied the effect of free chlorine on the nitritation process of a biological aerated filter. The results showed that the accumulation rate of $\mathrm{NO}_{2}^{-}-\mathrm{N}$ reached $60 \sim 70 \%$ when the free chlorine concentration in influent was $4 \mathrm{mg} / \mathrm{L}$ after 20 days. Song et al. [13] added $0.2 \mathrm{mg} / \mathrm{L}$ chlorine into an SBR reactor 1 hour after the start of the reaction. It was found that $\mathrm{NO}_{2}^{-}-\mathrm{N}$ started to accumulate when the reactor had been running for 10 17 days, and the transformation from $\mathrm{NO}_{2}^{-}-\mathrm{N}$ to $\mathrm{NO}_{3}^{-}-\mathrm{N}$ was almost completely inhibited on the $20^{\text {th }}$ day. According to $\mathrm{Li}$ et al. [14], control of the reaction endpoint $\mathrm{pH}$ to $8.17 \sim 8.19$ in the process of treating landfill leachate with SBR, the effluent $\mathrm{NO}_{2}{ }^{-}-\mathrm{N} / \mathrm{NH}_{4}^{+}-\mathrm{N}$ ratio value stabilized to 1.1 1.5. $\mathrm{Gu}$ et al. [15] reported that partial nitritation could be achieved in the SBR system at $11 \sim 16^{\circ} \mathrm{C}$ within 40 days and be stably running for up to 140 days via applying a real-time control method over $\mathrm{pH}$ and blower frequency. Among all these methods, the longterm addition of free chlorine would not only increase costs but also lead to secondary pollution. Additionally, most studies on $\mathrm{pH}$ effect have been aimed at the activated sludge system, while the studies on the startup strategy and microbial structure of partial nitritation in the CRI system have not been reported. Unlike the activated sludge system, the substrates in the CRI system are in a non-flowing state. The influent condition changes with the increase of the filter depth, and it is difficult to achieve efficient and stable accumulation of $\mathrm{NO}_{2}^{-}-\mathrm{N}$ just by adding free chlorine or changing $\mathrm{pH}$ alone. The distribution of pollutants and dissolved oxygen in different filter depth varies, so filter depth is also an important factor affecting nitrification efficiency, which should be taken into account in the start-up of partial nitritation in a CRI system. Therefore, it is of great necessity to explore the synergistic regulation strategy for the start-up of partial nitritation in a CRI system.

In view of this, this study investigated the effect of synergistic regulation of free chlorine, filter height and influent $\mathrm{pH}$ on the transformation of nitrogen pollutants in a CRI system, and explored the feasibility of this regulation strategy to achieve partial nitritation in a CRI system. Furthermore, the mechanism of partial nitritation was revealed via analyzing the characteristics of microbial community structure in a stable operation period. Such information will provide technical reference for the regulation of partial nitritation in a CRI system and create suitable influent conditions for the subsequent ANAMMOX. 


\section{Materials and Methods}

\section{Experimental Equipment}

As shown in Fig. 1, the CRI reactor was made of polyvinyl chloride with an internal diameter of $7 \mathrm{~cm}$ and a filter height of $120 \mathrm{~cm}$. Water sampling ports were set at $60,75,90,105$ and $120 \mathrm{~cm}$ of filter height. On the other side, sand sampling ports were set at each $25 \mathrm{~cm}$ filter layer and numbered from top to bottom by PN1 to PN5. Filter material used natural river sand (particle size $0.1 \sim 0.4 \mathrm{~mm}$ ), shell sand (particle size $0.5 \sim 1.2 \mathrm{~mm}$ ) and zeolite sand (particle size $0.8 \sim 1.5 \mathrm{~mm}$ ) that mixed well with a mass ratio of 7:2:1. The top and bottom of the filter were each laid with a layer of gravel (particle size $5 \sim 18 \mathrm{~mm}$ ), respectively acting as a buffer and a supporting role. Annular pipe was adopted to distribute water evenly, influent was adjusted by peristaltic pump and rotor flowmeter, and the temperature during the experiment was maintained at $25 \pm 1^{\circ} \mathrm{C}$.

\section{Influent and Seeding Sludge}

To reduce the disturbance of water quality fluctuation, $\mathrm{C}_{6} \mathrm{H}_{12} \mathrm{O}_{6}, \mathrm{NH}_{4} \mathrm{Cl}, \mathrm{NaNO}_{2}, \mathrm{KNO}_{3}$ and $\mathrm{KH}_{2} \mathrm{PO}_{4}$ were added to tap water to simulate domestic sewage for the experiment. The theoretical concentration of influent $\mathrm{COD}, \mathrm{NH}_{4}^{+}-\mathrm{N}, \mathrm{NO}^{-}-\mathrm{N}$ and $\mathrm{TP}$ were $120 \sim 160$, 45 50, 0.05 0.37 and 2.1 4.5 mg/L, respectively. Add $0.1 \mathrm{~mol} / \mathrm{L} \mathrm{HCl}$ and $\mathrm{NaOH}$ to adjust the influent $\mathrm{pH}$ value, and add an appropriate amount of $\mathrm{NaHCO}_{3}$ to supplement alkalinity. Meanwhile, $0.1 \mathrm{~mL}$ of nutrient solution was added to every $10 \mathrm{~L}$ of influent, and its components were as follows: $\mathrm{KCl} 2100 \mathrm{mg} / \mathrm{L}, \mathrm{NaCl}$ $1500 \mathrm{mg} / \mathrm{L}, \quad \mathrm{CaCl}_{2} \cdot 2 \mathrm{H}_{2} \mathrm{O} 2800 \mathrm{mg} / \mathrm{L}, \quad \mathrm{MgSO}_{4} \cdot 7 \mathrm{H}_{2} \mathrm{O}$

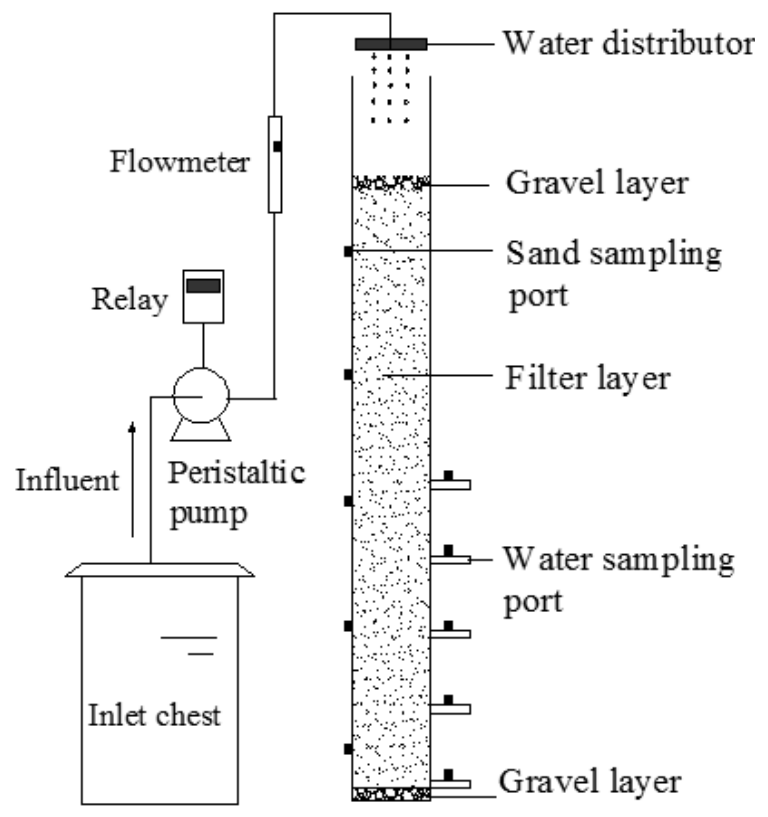

Fig. 1. Schematic of experimental equipment.
$2000 \mathrm{mg} / \mathrm{L}, \quad \mathrm{FeSO}_{4} \cdot 7 \mathrm{H}_{2} \mathrm{O} \quad 150 \mathrm{mg} / \mathrm{L}, \quad \mathrm{ZnSO}_{4} \cdot 5 \mathrm{H}_{2} \mathrm{O}$ $50 \mathrm{mg} / \mathrm{L}, \mathrm{MnCl}_{4} \cdot 4 \mathrm{H}_{2} \mathrm{O} 50 \mathrm{mg} / \mathrm{L}$, and $\mathrm{CuSO}_{4} \cdot 5 \mathrm{H}_{2} \mathrm{O}$ $30 \mathrm{mg} / \mathrm{L}$. The seeding sludge was collected from the returned sludge $($ MLSS $=7600 \mathrm{mg} / \mathrm{L}$ ) of a sewage treatment plant in Chengdu, China. The CRI system was started by gradually lifting the hydraulic loading, and it ran for 2 cycles per day, 12 hours per cycle. The ratio of flooding and draining time was 1:2. The biofilm culturing completed when the hydraulic loading reached $1.0 \mathrm{~m} / \mathrm{d}$ and the removal rates of $\mathrm{COD}$ and $\mathrm{NH}_{4}{ }^{+}-\mathrm{N}$ were stable at about $80 \%$.

\section{Experiments Performed}

Stage I (free chlorine regulation): During the second cycle of daily experiment, influent was changed to tap water to which $\mathrm{NaClO}$ was added to make the concentration of free chlorine in water $3 \mathrm{mg} / \mathrm{L}$. Water samples were taken from the sampling port at $105 \mathrm{~cm}$ after the end of daily operation. When $\mathrm{NH}_{4}^{+}-\mathrm{N}$ removal and $\mathrm{NO}_{2}^{-}-\mathrm{N}$ accumulation became stable, the chlorine supply was stopped and the original influent state was restored.

Stage II (filter height regulation): The effluent quality at the filter height of $60,75,90,105$ and $120 \mathrm{~cm}$ was respectively investigated during the stable operation of the CRI system, and the optimum effluent filter height for partial nitritation was explored.

Stage III (influent $\mathrm{pH}$ regulation): Adjust the influent $\mathrm{pH}$ value to $7.3,7.6,7.9,8.2,8.5$ and 8.8 respectively, and analyze the impact of influent $\mathrm{pH}$ on nitrogen pollutant transformation. When $\mathrm{NH}_{4}^{+}-\mathrm{N}$ removal rate and $\mathrm{NO}_{2}^{-}-\mathrm{N}$ accumulation rate were stable at around $60 \%$ and $90 \%$ respectively, and the effluent $\mathrm{NO}_{2}{ }^{-}-\mathrm{N} / \mathrm{NH}_{4}{ }^{+}-\mathrm{N}$ ratio was close to 1.32 , it marked the successful realization of partial nitritation in the CRI system. On this basis, sand samples were taken from different filter heights for analysis of microbial community structure, which provided the basis for analyzing the mechanism of partial nitritation in the CRI system. It should be noted that different CRI systems may have different treatment performances even under the same start-up conditions. In order to avoid the experimental errors caused by the differences among different CRI systems, each regulation experiment in this study was carried out in one CRI system. The data obtained from the regulation experiments were compared with those from the initial experiment lest the errors resulting from setting separate parallel groups occur.

\section{Analytical Methods \\ Analysis of Water Quality}

The concentrations of $\mathrm{NH}_{4}^{+}-\mathrm{N}, \mathrm{NO}_{2}^{-}-\mathrm{N}, \mathrm{NO}_{3}^{-}-\mathrm{N}$ and COD in water samples were measured by standard methods (APHA, 1998). The values of $\mathrm{pH}$ and DO were detected by a $\mathrm{pH}$ meter (PHS-3C+ $\mathrm{C}^{+}$INESA, China) and 
a DO meter (DO200, YSI, USA), respectively. The content of free chlorine was determined by the iodometry method. The calculation methods of $\mathrm{NH}_{4}{ }^{+} \mathrm{N}$ removal rate (ARR), $\mathrm{NO}_{2}^{-}-\mathrm{N}$ accumulation rate (NAR) and effluent $\mathrm{NO}_{2}^{-}-\mathrm{N} / \mathrm{NH}_{4}^{+}-\mathrm{N}$ ratio (NNR) were as follows:

$$
\begin{gathered}
\operatorname{ARR}(\%)=\frac{\text { inf. } \mathrm{NH}_{4}{ }^{+}-\mathrm{N}-\text { eff. } \mathrm{NH}_{4}{ }^{+}-\mathrm{N}}{\text { inf. } \mathrm{NH}_{4}{ }^{+}-\mathrm{N}} \times 100 \% \\
\mathrm{NAR}(\%)=\frac{\text { eff. } \mathrm{NO}_{2}{ }^{-}-\mathrm{N}}{\text { eff. } \mathrm{NO}_{2}{ }^{-}-\mathrm{N}+{\text { eff. } \mathrm{NO}_{3}{ }^{-}-\mathrm{N}}_{10}} \times 100 \% \\
\mathrm{NNR}=\frac{\text { eff. } \mathrm{NO}_{2}{ }^{-}-\mathrm{N}}{\text { eff. } \mathrm{NH}_{4}{ }^{+}-\mathrm{N}}
\end{gathered}
$$

...where inf. $\mathrm{NH}_{4}^{+}-\mathrm{N}$, eff. $\mathrm{NH}_{4}^{+}-\mathrm{N}$, eff. $\mathrm{NO}_{2}^{-}-\mathrm{N}$ and eff. $\mathrm{NO}_{3}^{-}-\mathrm{N}$ respectively represents the concentration of influent $\mathrm{NH}_{4}^{+}-\mathrm{N}$, effluent $\mathrm{NH}_{4}^{+}-\mathrm{N}, \quad \mathrm{NO}_{2}^{-}-\mathrm{N}$ and $\mathrm{NO}_{3}^{-}-\mathrm{N}, \mathrm{mg} / \mathrm{L}$.

\section{Analysis of Microbial Community}

DNA extraction: after the partial nitritation of the CRI system was stable, appropriate filter materials were taken out from the sand sampling ports PN1, PN2 and PN3. In the conical bottle with particle size of $2 \sim 3 \mathrm{~mm}$ glass beads on the bottom, $100 \mathrm{~mL}$ phosphate buffer solution was added, and the vortex oscillated for $60 \mathrm{~min}$ to fully peel the biofilm on the filter surface. Then the mixture was removed and centrifuged at $10000 \mathrm{rpm}$ for $10 \mathrm{~min}$ at $4^{\circ} \mathrm{C}$, the supernatant was discarded, the precipitate was collected, and DNA was extracted using a DNA extraction kit (MO BIO Laboratories, USA).

16S rRNA high-throughput sequencing: the extracted DNA samples were sent to Sangon Biotech (Shanghai, China) Co., Ltd. for Miseq high-throughput sequencing. The corresponding primers were $515 \mathrm{~F}\left(5^{\prime}-\right.$ GTGCCAGCMGCCGCGGTAA-3') and 909R(5'CCCCGYCAATTCMTTTRAGT-3') targeting the V4 region of bacterial 16S rRNA. The PCR reaction conditions were as follows: pre-denaturation at $94^{\circ} \mathrm{C}$ for $3 \mathrm{~min}, 30$ cycles of pre-denaturating for $40 \mathrm{~s}$ at $94^{\circ} \mathrm{C}$, annealing for $60 \mathrm{~s}$ at $56^{\circ} \mathrm{C}$ and extension for $60 \mathrm{~s}$ at $72^{\circ} \mathrm{C}$, and finally extension for $10 \mathrm{~min}$ at $72^{\circ} \mathrm{C}$.

\section{Results and Discussion}

\section{Effects of Free Chlorine on Nitrogen Transformation}

The transformation of nitrogen pollutants in the CRI system before and after chlorine addition is shown in Fig. 2. Before chlorine addition (phase I), ARRs were stable at around $80 \%$, with a higher concentration of $\mathrm{NO}_{3}^{-}-\mathrm{N}$ in the effluent and less than $2 \%$ of $\mathrm{NO}_{2}^{-}-\mathrm{N}$ accumulation rate, indicating that the transformation
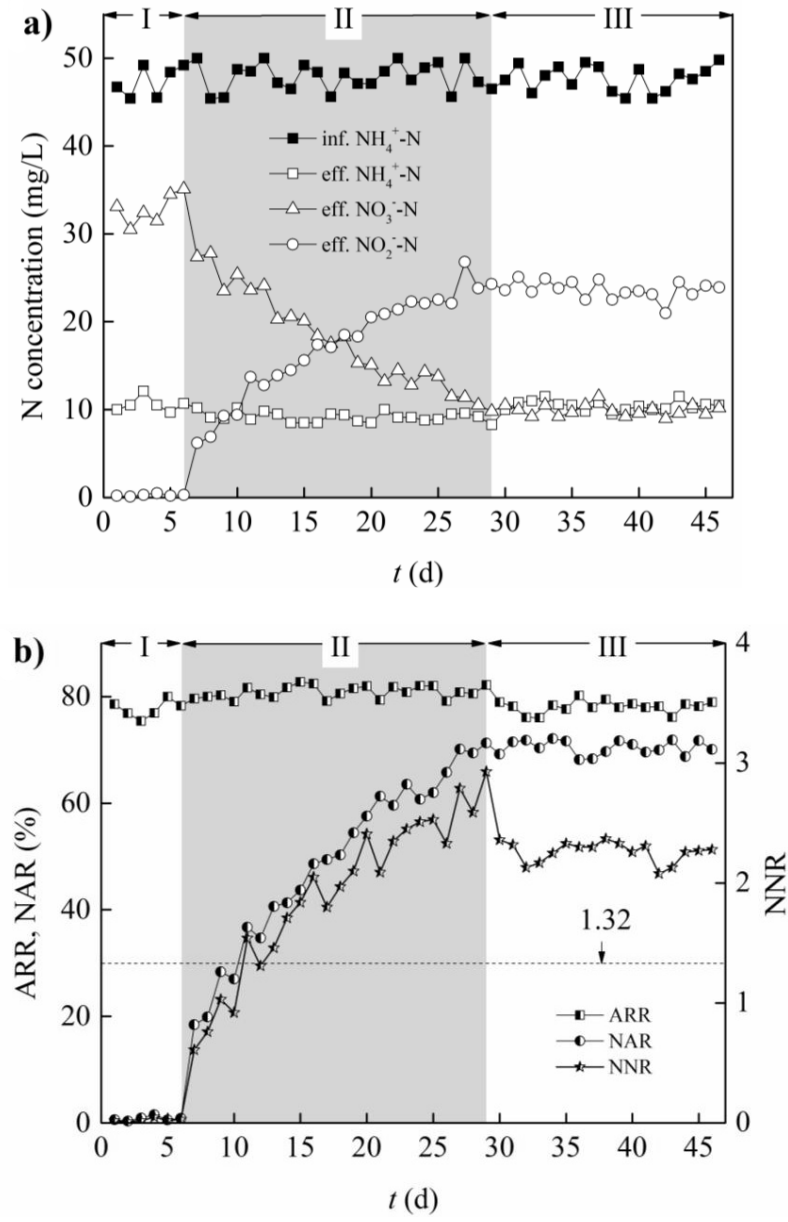

Fig. 2. Nitrogen transformation before and after chlorine addition: a) variations of $\mathrm{NH}_{4}^{+}-\mathrm{N}, \mathrm{NO}_{3}^{-}-\mathrm{N}$ and $\mathrm{NO}_{3}^{-}-\mathrm{N}$ concentrations; b) variations of ARR, NAR and NNR.

of nitrogen pollutants in the CRI system during the stable operation period was dominated by complete nitrification, that is, most of $\mathrm{NH}_{4}^{+}-\mathrm{N}$ was finally converted into $\mathrm{NO}_{3}^{-}-\mathrm{N}$.

After $3 \mathrm{mg} / \mathrm{L}$ free chlorine was added (phase II), the removal rate of $\mathrm{NH}_{4}^{+} \mathrm{N}$ was slightly increased compared with phase I. As the days of chlorine addition increased, the effluent concentration of $\mathrm{NO}_{3}^{-}-\mathrm{N}$ gradually decreased and the concentration of $\mathrm{NO}_{2}^{-}-\mathrm{N}$ gradually increased. After 23 days of continuous chlorine addition, the NAR reached $71.3 \%$, and began to change from complete nitrification to partial nitrification. After the stable operation of phase II, it entered phase III (no free chlorine supply), and the NAR remained above $70 \%$ by the $17^{\text {th }}$ day, and the NNR was greater than 2.0. It can be seen that free chlorine can effectively inhibit the transformation from $\mathrm{NO}_{2}^{-}-\mathrm{N}$ to $\mathrm{NO}_{3}^{-}-\mathrm{N}$, and such an inhibitory effect was difficult to recover from in the short term. According to previous studies, some chemicals - such as chlorate [16], hydroxylamine [17] and methanoic acid [18] - may have different inhibitory effects on the activities of ammonia-oxidizing bacteria (AOB) and nitriteoxidizing bacteria (NOB) involved in nitrification. 
By controlling the appropriate concentration of inhibitor, NOB could be selectively eliminated while having little impact on AOB. Therefore, the further transformation of $\mathrm{NO}_{2}^{-}-\mathrm{N}$ to $\mathrm{NO}_{3}^{-}-\mathrm{N}$ could be inhibited without affecting the oxidation of $\mathrm{NH}_{4}^{+}-\mathrm{N}$ to $\mathrm{NO}_{2}^{-}-\mathrm{N}$, and the efficient accumulation of $\mathrm{NO}_{2}^{-}-\mathrm{N}$ could be achieved, which is similar to the results obtained in this study.

\section{Effect of Filter Height on Nitrogen Transformation}

The hydraulic residence time and DO distribution of sewage in the CRI system were different at different filter heights, which would affect the conversion efficiency of pollutants. Fig. 3 shows the effect of different filter heights on the transformation of nitrogen in the CRI system. As can be seen, $\mathrm{NH}_{4}^{+}-\mathrm{N}$ concentration in the range of $60 \sim 105 \mathrm{~cm}$ decreased with the increase of filter height, and the ARRs gradually increased. When the filter height was $120 \mathrm{~cm}$, the effluent $\mathrm{NH}_{4}^{+}-\mathrm{N}$ concentration increased instead, and the average removal rate decreased to $74.7 \%$. The concentration of $\mathrm{NO}_{3}^{-}-\mathrm{N}$ did not change much when the filter height was $60 \sim 90 \mathrm{~cm}$, then increased slightly when the filter height was $105 \mathrm{~cm}$, and began to decrease when it was over $105 \mathrm{~cm}$. The concentration of $\mathrm{NO}_{2}^{-}-\mathrm{N}$ increased first and then tended to be stable
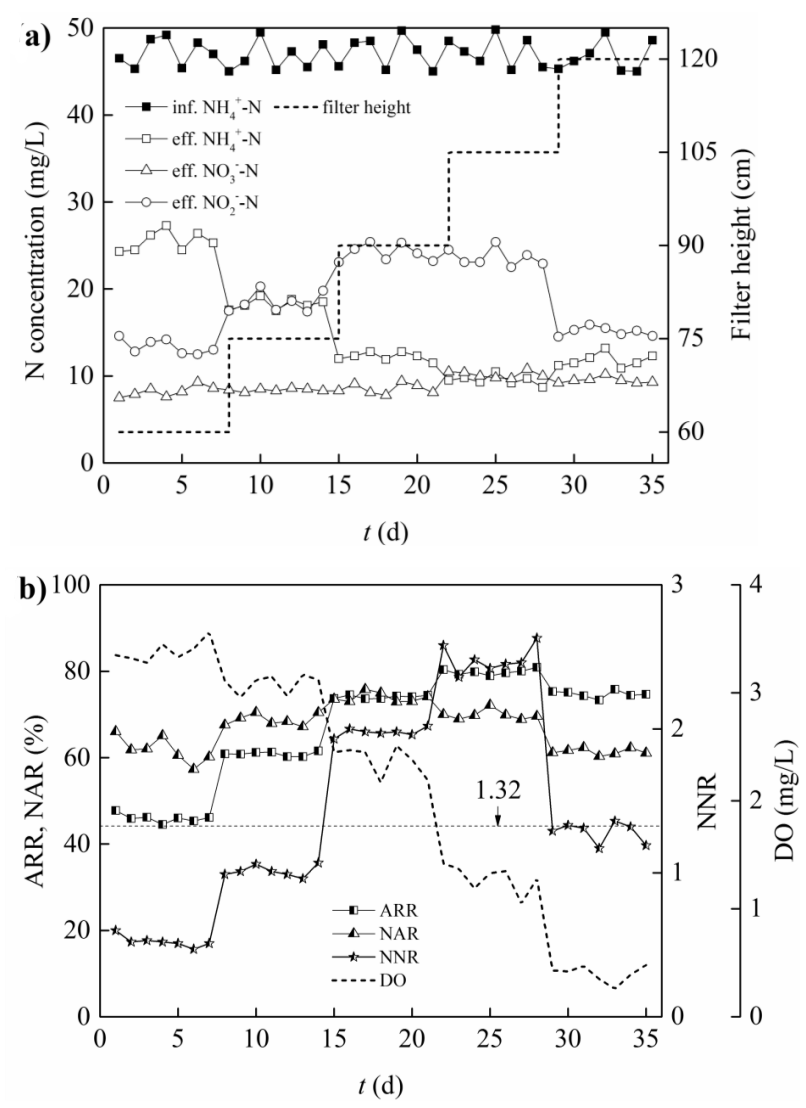

Fig. 3. Nitrogen transformation under different filter depths: a) variations of $\mathrm{NH}_{4}^{+}-\mathrm{N}, \mathrm{NO}_{3}^{-}-\mathrm{N}$ and $\mathrm{NO}_{3}^{-}-\mathrm{N}$ concentrations; b) variations of ARR, NAR and NNR. within the range of $60 \sim 105 \mathrm{~cm}$. When the filter height was $120 \mathrm{~cm}$, the concentration of $\mathrm{NO}_{2}^{-}-\mathrm{N}$ and the corresponding NARs decreased significantly.

The analysis showed that the CRI system was reoxygenated by alternately running between flooding and draining. When the filter height was $120 \mathrm{~cm}$, less oxygen could enter the bottom filter section, and the reoxygenation effect was ineffective, the DO concentration was only $0.26 \sim 0.48 \mathrm{mg} / \mathrm{L}$. As a result, an anoxic or anaerobic environment could be formed within the pores or biofilms of the filter material, and the process of dissimilatory nitrate reduction to ammonium (DNRA) could easily occur, that is, microorganisms used $\mathrm{NO}_{2}^{-}-\mathrm{N}$ or $\mathrm{NO}_{3}^{-}-\mathrm{N}$ as an electron acceptor to produce $\mathrm{NH}_{4}^{+}-\mathrm{N}$ under the action of nitrite reductase $(\mathrm{NiR})$ or nitrate reductase $(\mathrm{NaR})$ [19]. It has been reported that the DNRA process widely existed in the paddy soil [19], intertidal sediments [20], wetland [21] and other habitats. Schmidt et al. [22] found that filling sandy soil was beneficial to the occurrence of DNRA. Zheng et al. [23] reported that increased sand depth in the biological filter can create favorable conditions for DNRA. Similarly, the CRI system in this study adopted a variety of sand mixture filling as the filter material, and the increase of the filter height led to a significant reduction in the amount of DO, so the possibility of DNRA action was higher, which led to the reduction of $\mathrm{NO}_{2}^{-}-\mathrm{N}$ and $\mathrm{NO}_{3}^{-}-\mathrm{N}$ concentration in effluent and the increase of $\mathrm{NH}_{4}^{+}-\mathrm{N}$ concentration.

On the whole, when the filter height was $60 \mathrm{~cm}$ and the effluent NNR was only $0.47 \sim 0.60$, it cannot meet the requirement of ANAMMOX for influent. When the filter height was 90 105 cm, the effluent NNR was 1.93 2.63. As the influent of ANAMMOX, it was not only easy to cause the high concentration of $\mathrm{NO}_{2}{ }^{-} \mathrm{N}$ in effluent, but also possible to inhibit the ANAMMOX activity [24]. When the filter depth was $120 \mathrm{~cm}$, the effluent NNR was $1.17 \sim 1.36$, which was close to 1.32 , but the average NAR was only $61.4 \%$ as the concentration of $\mathrm{NO}_{2}^{-}-\mathrm{N}$ decreased significantly. In comparison, when the filter height was $75 \mathrm{~cm}$, the average ARR, NAR and NNR were $60.9 \%, 68.7 \%$ and $0.96 \sim 1.07$, respectively. Only by further selectively inhibiting the activity of NOB to further improving the $\mathrm{NO}_{2}^{-}-\mathrm{N}$ accumulation rate can influent requirements of ANAMMOX be satisfied. Therefore, $75 \mathrm{~cm}$ was selected as the suitable effluent filter height for the subsequent experiment.

\section{Effect of Influent pH on Nitrogen Transformation}

$\mathrm{AOB}$ and NOB are very sensitive to the acidity and alkalinity of the environment, and the influent $\mathrm{pH}$ value is a key factor affecting nitrification performance. Fig. 4 reflects the transformation of nitrogen pollutants under different influent $\mathrm{pH}$ conditions. It can be seen that the NAR increased slowly with the increase of influent $\mathrm{pH}$ value. The NAR jumped to $91.4 \%$ when the influent $\mathrm{pH}$ rose to 8.2 . It indicated that under this condition, 

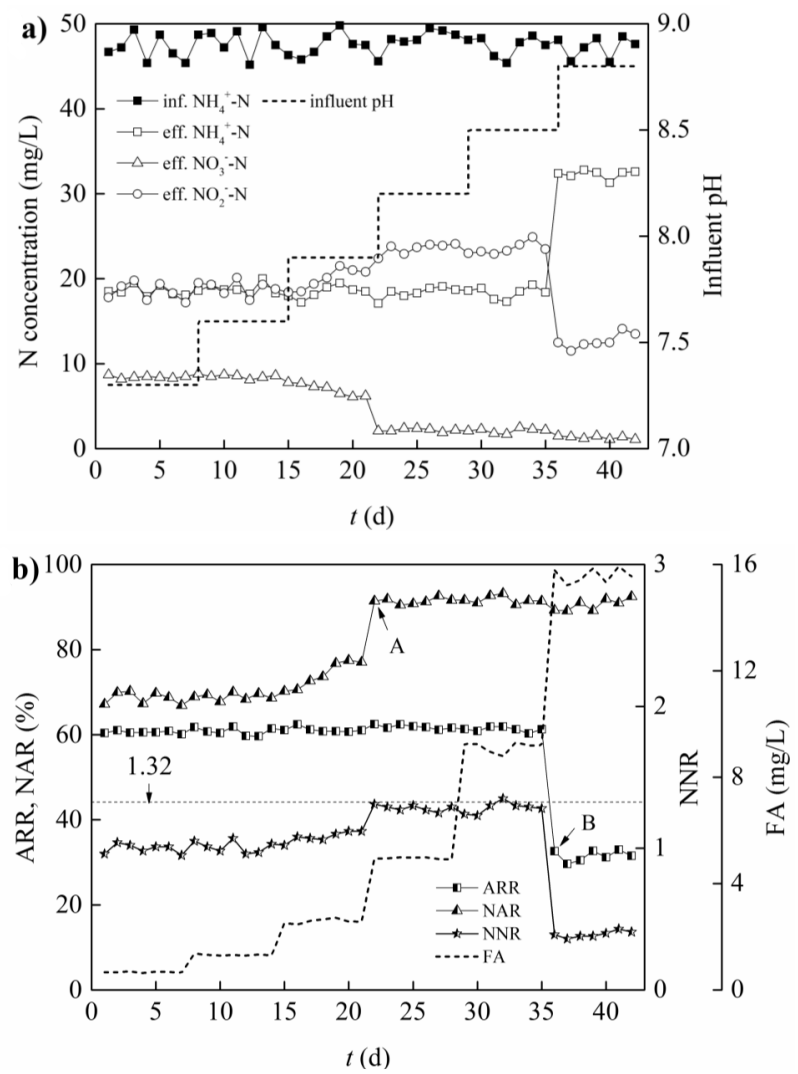

Fig. 4. Nitrogen transformation under different influent $\mathrm{pH}$ values: a) variations of $\mathrm{NH}_{4}^{+}-\mathrm{N}, \mathrm{NO}_{3}^{-}-\mathrm{N}$ and $\mathrm{NO}_{3}^{-}-\mathrm{N}$ concentrations; b) variations of ARR, NAR and NNR.

NOB activity was seriously inhibited, and $\mathrm{NO}_{2}^{-}-\mathrm{N}$ cannot be successfully converted into $\mathrm{NO}_{3}^{-}-\mathrm{N}$, resulting in increased $\mathrm{NO}_{2}^{-}-\mathrm{N}$ concentration in the effluent and significant reduction of $\mathrm{NO}_{3}^{-}-\mathrm{N}$ concentration. The ARRs remained at around $60 \%$ when the influent $\mathrm{pH}$ was 7.3 8.5, while the effluent $\mathrm{NH}_{4}^{+}-\mathrm{N}$ concentration significantly increased when the influent $\mathrm{pH}$ value increased to 8.8 , and the ARR reached a drop point (B), which dropped to $32.6 \%$. This indicated that under this condition, AOB activity started to be inhibited, and the conversion process of $\mathrm{NH}_{4}^{+}-\mathrm{N}$ to $\mathrm{NO}_{2}^{-}-\mathrm{N}$ was both blocked, leading to a significant reduction in $\mathrm{NH}_{4}^{+}-\mathrm{N}$ removal rate. To sum up, on the basis of chlorine addition and filter height regulation, the ARRs, NARs and NNRs were respectively stable at around 60\%, $90 \%$ and $1.23 \sim 1.35$ when the influent $\mathrm{pH}$ value was adjusted to 8.2 8.5. At this point, the partial nitritation in the CRI system was successfully achieved, and the influent requirements of ANAMMOX could be well matched.

According to the equation $\mathrm{NH}_{3}+\mathrm{H}_{2} \mathrm{O} \Leftrightarrow \mathrm{NH}_{4}^{+}+\mathrm{OH}^{-}$, the $\mathrm{pH}$ value would affect the concentration of free ammonia (FA) in the solution. As the real substrate used by $\mathrm{AOB}$ was $\mathrm{NH}_{3}$ instead of $\mathrm{NH}_{4}^{+}$, the change of $\mathrm{pH}$ would affect the process of nitrification and the composition of nitrifying bacteria. The calculation formula of FA is as follows [25]:

$$
\text { FA }\left(\mathrm{NH}_{3} / \mathrm{mg} \cdot \mathrm{L}^{-1}\right)=\frac{17}{14} \times \frac{\left[\mathrm{NH}_{4}^{+}-\mathrm{N}\right] \times 10^{\mathrm{pH}}}{\mathrm{e}^{6334 /(273+T)}+10^{\mathrm{pH}}}
$$

When the FA concentration was appropriate, it could be used as the ammonia oxidation matrix of $\mathrm{AOB}$, but when the FA concentration reached a certain threshold value, the activity of $\mathrm{AOB}$ and NOB would be inhibited to different degrees. Rongsayamanont et al. [26] determined that the initial concentration range of inhibition of FA on AOB and NOB was 60 120 and $0.6 \sim 60 \mathrm{mg} / \mathrm{L}$, respectively. Fux et al. [27] found that when the concentration of FA exceeded $5 \mathrm{mg} / \mathrm{L}$, it can inhibit AOB, while the concentration of FA that can completely inhibit NOB was only $0.6 \mathrm{mg} / \mathrm{L}$. Until now, there have been differences in the research conclusions about the inhibition concentration of FA on AOB and NOB, but all reflected that the sensitivity of NOB to FA was higher than that of AOB.

In this study, the average FA concentration corresponding to each $\mathrm{pH}$ value was $0.67,1.32,2.59$, $4.95,9.14$, and $15.59 \mathrm{mg} / \mathrm{L}$, respectively. $\mathrm{NO}_{2}^{-}-\mathrm{N}$ accumulation appeared at a jump point (A) when FA concentration was $4.95 \mathrm{mg} / \mathrm{L}$, indicating that NOB activity was severely inhibited at this point. NAR was still higher when FA concentration increased to $9.14 \mathrm{mg} / \mathrm{L}$, implying that AOB had stronger adaptability when FA concentration was 4.95 9.14 $\mathrm{mg} / \mathrm{L}$. The removal rate of $\mathrm{NH}_{4}^{+}-\mathrm{N}$ appeared a drop point (B) when FA concentration increased to $15.59 \mathrm{mg} / \mathrm{L}$, indicating that when FA concentration was too high, it would also significantly inhibit AOB activity, leading to increased $\mathrm{NH}_{4}^{+}-\mathrm{N}$ concentrations in effluent and decreased $\mathrm{NO}_{2}^{-}-\mathrm{N}$ concentrations.

\section{Microbial Community Structure}

\section{Microbial Richness and Diversity}

A total of 130687 effective sequences were obtained by $16 \mathrm{~S}$ rRNA high-throughput sequencing, and the effective sequence ratio was higher than $90 \%$. In order to analyze the microbial richness and diversity of the filler samples, the effective sequences were analyzed by cluster analysis under the similarity level of $97 \%$, and the obtained numbers of OUT from PN1, PN2 and PN3 were 1714, 1940 and 1859, respectively. A certain number of sequences were randomly selected to count the number of species they represent. The rarefaction curves constructed are shown in Fig. 5. It can be seen that the rarefaction curves all tended to be flat at a similarity level of $97 \%$, indicating that the sequencing depth was reasonable and the sequencing results could reflect the microbial community structure accurately [28].

Alpha diversity index analysis results are shown in Table 1. The Chaol index reflected the microbial richness, and the larger the value, the higher the microbial richness. The Shannon index and Simpson index both reflected the microbial diversity. The larger 


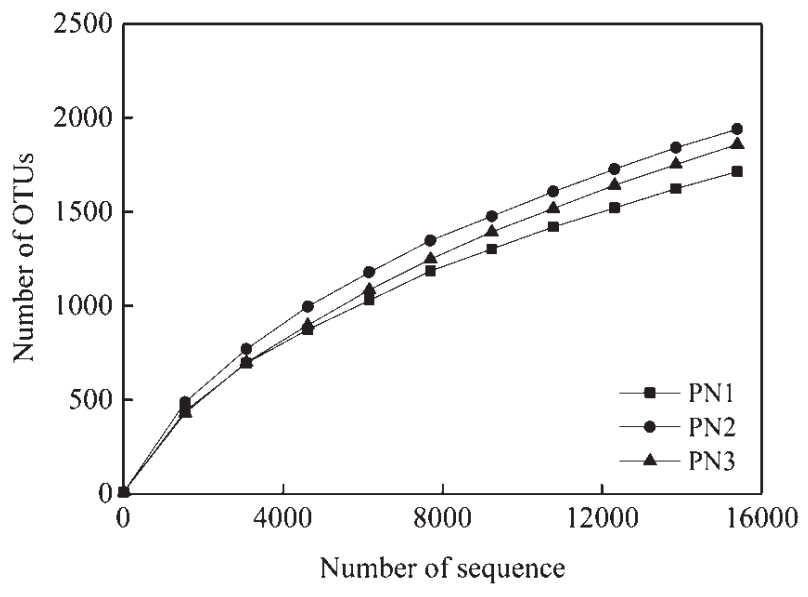

Fig. 5. Rarefaction curves of each sample.

the Shannon index, the higher the microbial diversity; while the larger the Simpson index, the lower the microbial diversity [29]. According to Table 1, the Shannon indexes of the 3 samples were successively PN2 $>$ PN1 $>$ PN3, while the order of the Simpson index was the opposite. This indicated that the microbial diversity in the middle layer (PN2) of filter segment was the highest, which was because the environmental conditions of the middle layer of filter segment were relatively stable, which was conducive to the growth of microorganisms in different populations, and therefore the distribution uniformity of each microbial community was also higher. The Chaol indexes were successively $\mathrm{PN} 3>\mathrm{PN} 2>\mathrm{PN} 1$, indicating that the microbial richness decreased with the increase of filter depth. This was because the nutrients in the sewage were degraded step by step in the CRI system with the increase of filter depth, and thus the microbial community richness decreased accordingly.

PCoA analysis was performed on the OTU composition of 3 samples, and the result is shown in Fig. 6. The contribution rate of principal component 1 (PCoA1) and principal component 2 (PCoA2) in Fig. 6 were respectively $60.11 \%$ and $16.79 \%$, and the distance between points indicated the difference degree of OTU composition [30]. As seen, the distance between point PN1 with point PN2 and PN3 was far, indicating that the OUT composition of the upper filter and the middle and lower filter was quite different, thus the microbial community structure was obviously different. However, the distance between point PN2 and PN3 was relatively close, indicating that the OTU composition of the

Table 1. Alpha diversity indexes of each sample.

\begin{tabular}{|c|c|c|c|}
\hline Sample ID & Shannon & Chao1 & Simpson \\
\hline PN1 & 7.30 & 3270.67 & 0.95 \\
\hline PN2 & 7.79 & 3374.69 & 0.94 \\
\hline PN3 & 7.13 & 3380.08 & 0.96 \\
\hline
\end{tabular}

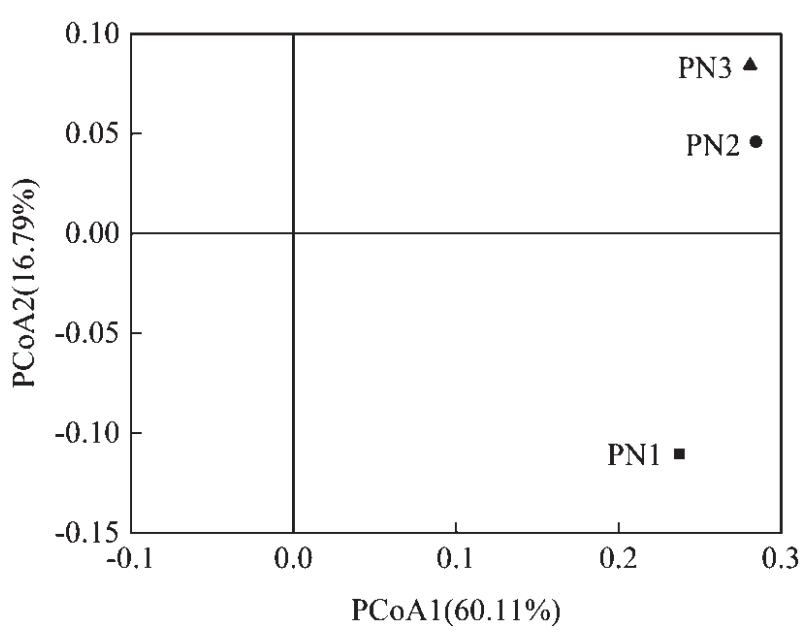

Fig. 6. PCoA graph based on weighted Unifrac distance.

middle filter and the lower filter was relatively similar, therefore the microbial community structure difference was relatively small.

\section{Community Structure and Distribution}

\section{Phylum Level}

Fig. 7 shows the main microbial structure and distribution at phylum level in each sample. Of the detected 41 known phyla, the relative abundance higher than $1 \%$ in each sample were mainly Proteobacteria (66.89\% 81.54\%), Acidobacteria $\quad(4.41 \% \sim 13.19 \%)$, Crenarchaeota $\quad(2.38 \% \sim 6.33 \%), \quad$ Bacteroidetes $(2.39 \% \sim 4.25 \%)$ and Actinobacteria $(1.73 \% \sim 2.68 \%)$. The relative abundance of Proteobacteria in 3 samples was successively $\mathrm{PN} 3>\mathrm{PN} 1>\mathrm{PN} 2$. The relative abundance of Acidobacteria and Chloroflexi in the middle of the filter was the highest, while the relative abundance of Crenarchaeota, Bacteroidetes and Actinobacteria decreased with the increase of filter depth. It can be seen that the microbial abundance of different filter heights was quite different, and the microbial community changed with the migration and transformation of pollutants in the CRI system.

Proteobacteria had the highest relative abundance in 3 samples, and it was a common dominant phylum in the sewage treatment system. The bacteria of this phylum were diversified and of various species, covering a wide range of physiological metabolic types such as aerobic, anaerobic, autotrophic and heterotrophic, which were closely related to the metabolism of $\mathrm{C}, \mathrm{N}$, and $\mathrm{S}$, and provided a basis for efficient removal or transformation of pollutants in the CRI system [31]. Acidobacteria was widely distributed in soil, lake sediments and activated sludge, which was vital for the ecological construction and material circulation of the CRI system. Its distribution was affected by various factors such as $\mathrm{pH}$, $\mathrm{C} / \mathrm{N}$ and DO [32]. Crenarchaeota was a major branch of archaea, and usually lived in extreme environments such as low $\mathrm{pH}$, high temperature and high salt. 


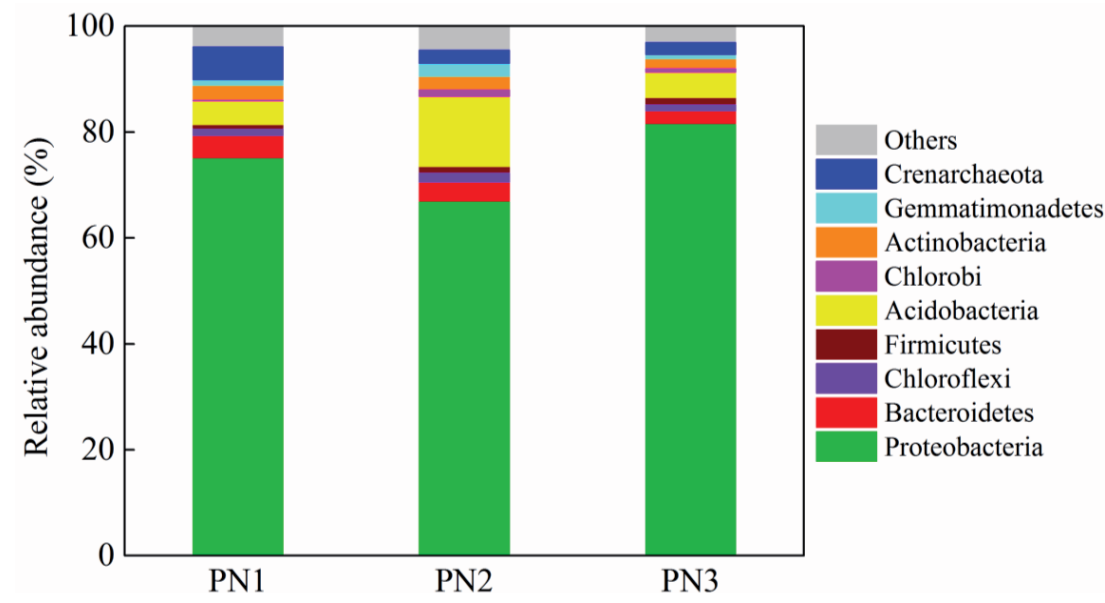

Fig. 7. Microbial community distribution at the phylum level in each sample.

With the in-depth study of environmental biotechnology in the field of microbiology, researchers have successively found a large number of Crenarchaeota in non-extreme environments, such as the soil, lake, grassland, freshwater and sewage treatment system, which played an important role in the material cycle of $\mathrm{C}$ and $\mathrm{N}[33,34]$. Both Bacteroidetes and Actinobacteria can degrade organic matter in sewage, which existed widely in an environment with rich organic matter content $[35,36]$. As organic matter was degraded step by step in the CRI system, their relative abundance in the lower part of the filter was the lowest. In addition, the phyla such as Chloroflexi, Gemmatimonadetes, Firmicutes and Chlorobi were also detected. Although their relative abundance was not as high as the above phyla, they all played an indispensable role in the sewage treatment of the CRI system.

\section{Class Level}

A total of 144 known classes were identified and the distribution of dominant classes is shown in Fig. 8. The relative abundance higher than $1 \%$ in each filter layer were mainly $\beta$-proteobacteria (15.02 45.54\%), $\delta$-proteobacteria $\quad(18.22 \sim 40.12 \%), \quad \gamma$-proteobacteria $(4.23 \sim 23.59 \%), \quad \alpha$-proteobacteria $\quad(4.51 \sim 6.93 \%)$, iii1$8(1.11 \sim 8.79 \%)$, Thaumarchaeota $\quad(2.36 \sim 6.33 \%)$ and Saprospirae (1.06 2.12\%).

$\beta$-proteobacteria had the highest relative abundance in Proteobacteria. Hu et al. [37] collected activated sludge from 12 sewage plants of different types for analysis and found that the relative abundance of $\beta$-proteobacteria was higher at class level. $\beta$-proteobacteria included various aerobic and facultative bacteria, such as Nitrosomonas, Nitrosovibrio and Thauera, which were related to nitrogen removal and provided conditions for the transformation of nitrogen pollutants in the CRI system. In addition, Thaumarchaeota had the highest relative abundance in Crenarchaeota, and its proportion decreased with the increase of filter depth. In the genome of Thaumarchaeota, there was the gene amo $A$ sequence that can encode ammonia monooxygenase (AMO) [38], so it can carry out ammoxidation. As a type of ammonia-oxidizing archaea (AOA), Thaumarchaeota was an important participant in the nitrogen cycle and played an active role in the biological nitrogen removal of sewage.

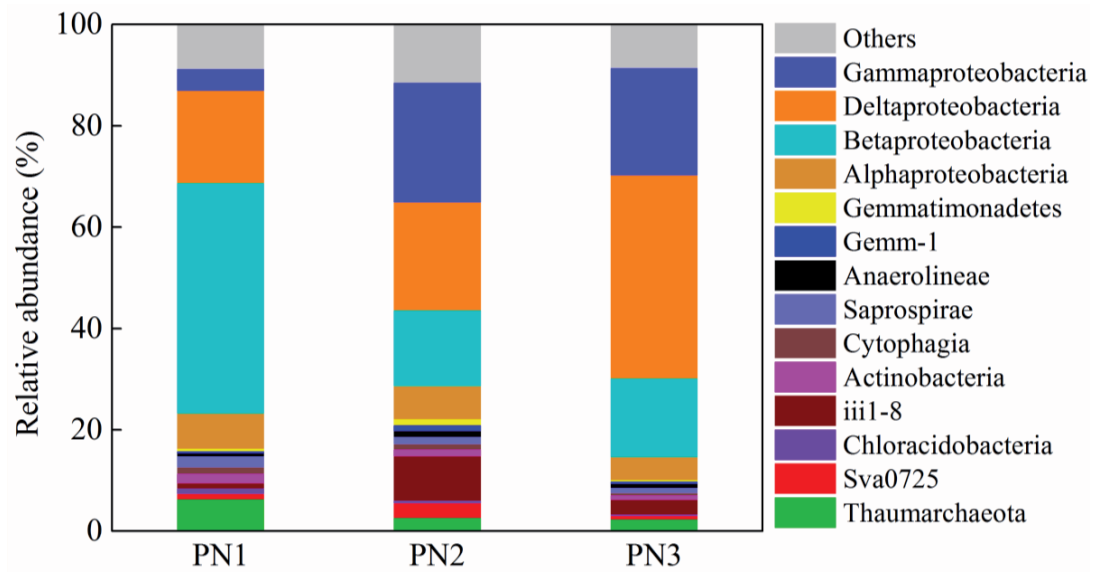

Fig. 8. Microbial community distribution at the class level in each sample. 


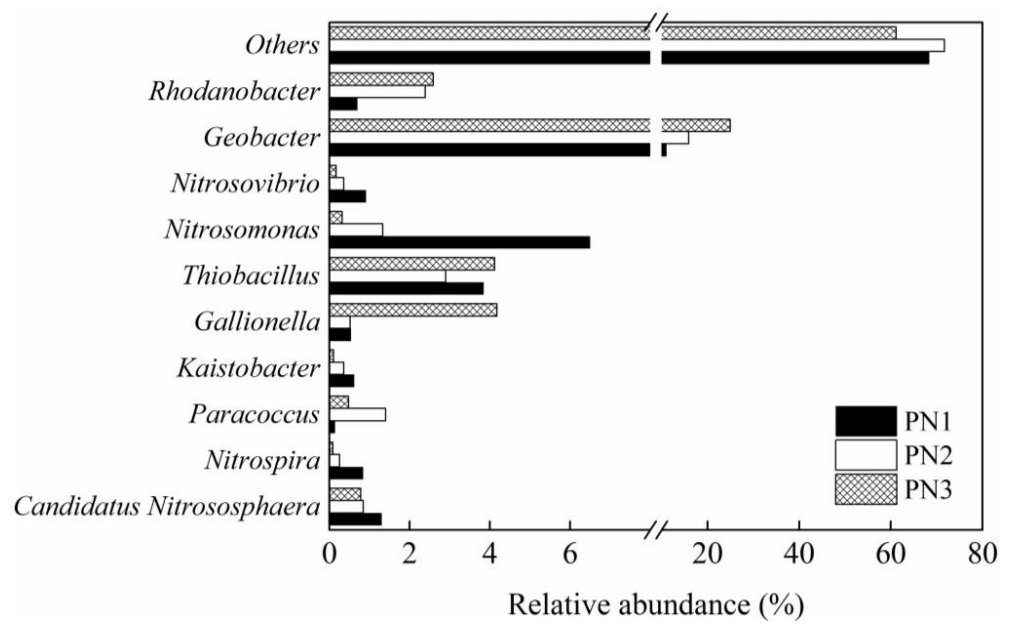

Fig. 9. Microbial community distribution at the genus level in each sample.

\section{Genus Level}

Fig. 9 shows the main microbial structure and distribution at genus level in each sample. Of the detected 310 known genera, Nitrosomonas and Nitrosovibrio belonging to $\beta$-proteobacteria, Candidatus Nitrososphaera belonging to Thaumarchaeota and Nitrospira belonging to Nitrospira were found to be associated with nitrogen transformation.

Nitrosomonas and Nitrosovibrio were the most common types of AOB in wastewater biological treatment while Candidatus Nitrososphaera was typical AOA with ammonia oxidation function, and all of them can convert $\mathrm{NH}_{4}^{+}-\mathrm{N}$ in sewage to $\mathrm{NO}_{2}^{-}$ -N. Limpiyakorn et al. [39] investigated the ammoniaoxidizing bacteria in 12 sewage treatment systems and found that the dominant bacteria in AOB were all Nitrosomonas. Tietz et al. [40] found that the major species of ammonia-oxidizing bacteria in vertical flow artificial wetland (VFCWs) were Nitrosomonas and Nitrosospira. Wang et al. [41] used a biological filter to treat simulated high ammonia livestock breeding wastewater, the results showed that the main AOB in the biological filter were Nitrosomonas and Nitrosovibrio. Compared with the above reports, the dominant species of ammonia-oxidizing microorganisms in this study were more abundant, which was related to the unique operation mode (flooding-draining alternative operation) of the CRI system and the filter material structure (mix sand with different particle sizes) providing a rich ecological niche for different types of microorganisms. The relative abundance of Nitrosomonas, Nitrosovibrio and Candidantus Nitrososphaera were respectively $0.31 \sim 6.49 \%, 0.17 \sim 0.91 \%$ and $0.78 \sim 0.84 \%$, indicating that Nitrosomonas had an absolute advantage in ammoniaoxidizing microorganisms. As the filter depth increased, $\mathrm{NH}_{4}^{+}-\mathrm{N}$ and DO concentration decreased step by step, so the relative abundance of the above ammoniaoxidizing microorganisms showed a decreasing trend as filter depth increased.
As the most common type of NOB in wastewater biological treatment, Nitrospira can further convert $\mathrm{NO}_{2}^{-}-\mathrm{N}$ into $\mathrm{NO}_{3}^{-}-\mathrm{N}$, but its relative abundance was only $0.08 \sim 0.83 \%$, which is equivalent to only $6.7 \sim 10.0 \%$ of the total abundance of Nitrosomonas, Nitrosovibrio and Candidantus Nitrososphaera. This indicated that through the synergistic regulation of free chlorine, filter height and influent $\mathrm{pH}$, the NOB activity in the CRI system could be selectively inhibited, which was reduced significantly due to the low metabolic activity, thus achieving the enrichment of ammonia-oxidizing microorganisms. As the content of $\mathrm{AOB}$ and $\mathrm{AOA}$ in the CRI system was much higher than that of NOB, $\mathrm{NH}_{4}^{+}-\mathrm{N}$ could be transformed into $\mathrm{NO}_{2}^{-}-\mathrm{N}$, while $\mathrm{NO}_{2}^{-}$ $-\mathrm{N}$ cannot be oxidized into $\mathrm{NO}_{3}^{-}-\mathrm{N}$ smoothly and accumulated efficiently, resulting in the occurrence of partial nitritation in the CRI system.

\section{Conclusions}

The partial nitritation of the CRI system could be achieved successfully through the synergistic regulation of free chlorine, filter height and influent $\mathrm{pH}$. After continuously adding $3 \mathrm{mg} / \mathrm{L}$ of free chlorine for 23 days, adjusting the effluent height to $75 \mathrm{~cm}$ and the influent $\mathrm{pH}$ to $8.2 \sim 8.5$, the NARs and NNRs were respectively stable at around $90 \%$ and $1.23 \sim 1.35$, which well matched the influent requirement of subsequent ANAMMOX. The results of high-throughput sequencing indicated that the main species of microorganisms associated with nitrogen transformation at genus level were Nitrosomonas, Nitrosovibrio, Candidatus Nitrososphaera and Nitrospira. Among them, AOB mainly included Nitrosomonas and Nitrosovibrio. AOA mainly included Candidatus Nitrososphaera. NOB mainly included Nitrospira, and its relative abundance was only equivalent to $6.7 \sim 10.0 \%$ of $\mathrm{AOB}$ and $\mathrm{AOA}$. As a result, $\mathrm{NH}_{4}^{+}-\mathrm{N}$ could be successfully transformed into $\mathrm{NO}_{2}^{-}-\mathrm{N}$, while $\mathrm{NO}_{2}^{-}-\mathrm{N}$ cannot be further transformed 
into $\mathrm{NO}_{3}^{-}-\mathrm{N}$, providing favorable conditions for the occurrence of partial nitritation in the CRI system. These results provide a novel method for the regulation of partial nitritation in the CRI system and promote the development of CRI technology in treating low $\mathrm{C} / \mathrm{N}$ domestic wastewater.

\section{Acknowledgements}

This study was financially supported by the National Natural Science Foundation of China (grant No. 41502333), the Key Research and Development Project of Environmental Pollution Prevention and Control of Sichuan Province (grant No. 2017SZ0179), and the Sichuan Science and Technology Program (grant No. 2019JDRC0136).

\section{Conflict of Interest}

The authors declare no conflict of interest.

\section{References}

1. YANG L., KONG F.L., XI M., LI Y., WANG S. Environmental economic value calculation and sustainability assessment for constructed rapid infiltration system based on emergy analysis. Journal of Cleaner Production, 167, 582, 2017.

2. KANG A., WANG L., ZHANG B. A study on mechanism of organic matter removal in a three-step series constructed rapid infiltration system used for domestic wastewater treatment. Journal of Residuals Science \& Technology, $\mathbf{1 4}$ (1), 115, 2017.

3. WANG D.B., ZHANG Z.Y., LI X.M., ZHENG W., YANG Q., DING Y., ZENG T.J., CAO J.B., YUE X., SHEN T.T., ZENG G.M., DENG J.H. A full-scale treatment of freeway toll-gate domestic sewage using ecology filter integrated constructed rapid infiltration. Ecological Engineering, 36 (6), 827, 2010.

4. XU W. L., ZHANG W., JIAN Y., WANG J., TANG M., PEI X. J. Analysis of nitrogen removal performance of constructed rapid infiltration system (CRIS). Applied Ecology \& Environmental Research, 15 (1), 199, 2017.

5. HUANG X., URATA K., WEI Q., YAMASHITA Y., HAMA T., KAWAGOSHI Y. Fast start-up of partial nitritation as pre-treatment for anammox in membrane bioreactor. Biochemical Engineering Journal, 105, 371, 2016.

6. WANG Z., ZHANG S., ZHANG L., WANG B., LIU W., MA S., PENG Y. Restoration of real sewage partial nitritation-anammox process from nitrate accumulation using free nitrous acid treatment. Bioresource Technology, 251, 341, 2017.

7. VAL A.D.R., PICHEL A., FERNANDEZGONZALEZ N., PEDROUSO A., FRAVÁZQUEZ A., MORALES N., MENDEZ R., CAMPOS J.L., MOSQUERACORRAL A. Performance and microbial features of the partial nitritation-anammox process treating fish canning wastewater with variable salt concentrations. Journal of Environmental Management, 208, 112, 2018.
8. LU Y., MA L., LIANG Y., SHAN B., CHANG J. Enhancing nitrogen removal performance in a bioreactor using immobilized anaerobic ammonium oxidation sludge by polyvinyl alcohol-sodium alginate (PVA-SA). Polish Journal of Environmental Studies, 27 (2), 773, 2018.

9. ZHU W., LI J., DONG H., WANG D., ZHANG P. Effect of influent substrate ratio on anammox granular sludge: performance and kinetics. Biodegradation, 28, 437, 2017.

10. WANG B., ZHAO M., GUO Y., PENG Y., YUAN Y. Longterm partial nitritation and microbial characteristics in treating low $\mathrm{C} / \mathrm{N}$ ratio domestic wastewater. Environmental Science Water Research \& Technology, 4, 820, 2018.

11. MONBALLIU A., DESMIDT E., DE CLIPPELEIR H., VANDEWEYER H., VAN HULLE S., VERSTRAETE W., MEESSCHAERT B. Accumulation of anerobi ammonium oxidizing bacteria (anammox) in a continous lab scale reactor starting from conventional sludge. Materials Science in Semiconductor Processing, 14 (1), 69, 2011.

12. GE L.P., QIU L.P., LIU Y.Z., ZHANG S.B. Effect of free chlorine on shortcut nitrification in biological aerated filter. Journal of University of Jinan (Sci. and Tech.), 25 (4), 336, 2011.

13. SONG X.Q., PENG Y.Z., WANG S.Y., WANG Y.Y. Shortcut nitrification/denitrification by dosing inhibibor. Technology of Water Treatment, 31 (4), 38, 2005.

14. LI H., ZHOU S., HUANG G., XU B. Achieving stable partial nitritation using endpoint ph control in an SBR treating landfill leachate. Process Safety \& Environmental Protection, 92 (3), 199, 2014.

15. GU S., WANG S., YANG Q., YANG P., PENG Y. Start up partial nitrification at low temperature with a realtime control strategy based on blower frequency and $\mathrm{pH}$. Bioresource Technology, 112 (3), 34, 2012.

16. TATARI K., GÜLAY A., THAMDRUP B., ALBRECHTSEN H.J., SMETS B.F. Challenges in using allylthiourea and chlorate as specific nitrification inhibitors. Chemosphere, 182, 301, 2017.

17. XU G., XU X., YANG F., LIU S., GAO Y. Partial nitrification adjusted by hydroxylamine in aerobic granules under high DO and ambient temperature and subsequent anammox for low $\mathrm{C} / \mathrm{N}$ wastewater treatment. Chemical Engineering Journal, 21(12), 338, 2012.

18. LI N., HU X., LI G. Selective inhibition of nitrite oxidation by methanoic acid dosing in sequencing batch reactor. Environmental Engineering Science, 34 (2), 73, 2017.

19. SHAN J., XU Z., RONG S., XIA Y., TI C., QUAN X., WANG S., WEI W., YAN X. Dissimilatory nitrate reduction processes in typical chinese paddy soils: rates, relative contributions, and influencing factors. Environmental Science \& Technology, 50 (18), 9972, 2016.

20. YIN G., HOU L., LIU M., LI X., ZHENG Y., GAO J., JIANG X., WANG R., YU C., LIN X. Dissimilatory nitrate reduction to ammonium (DNRA) in intertidal sediments of the Yangtze Estuary. Journal of Geophysical Research Biogeosciences, 122 (8), 1988, 2017.

21. JAHANGIR M.M.R., FENTON O., MÜLLER C., HARRINGTON R., JOHNSTON P., RICHARDS K.G. In situ, denitrification and dnra rates in groundwater beneath an integrated constructed wetland. Water Research, 111, 254, 2017.

22. SCHMIDT C.S., RICHARDSON D.J., BAGGS E.M. Constraining the conditions conducive to dissimilatory nitrate reduction to ammonium in temperate arable soils. Soil Biology \& Biochemistry, 43 (7), 1607, 2011. 
23. ZHENG D., DENG L.W., FAN Z.H., LIU G.J., CHEN C., YANG H., LIU Y. Influence of sand layer depth on partial nitritation as pretreatment of anaerobically digested swine wastewater prior to anammox. Bioresource Technology, 104 (1), 274, 2012.

24. LOTTI T., WR V.D.S., KLEEREBEZEM R., LUBELLO C., VAN LOOSDRECHT M.C. The effect of nitrite inhibition on the anammox process. Water Research, 46 (8), 2559, 2012.

25. DONG H., ZHANG K., HAN X., DU B., WEI Q., WEI D. Achievement, performance and characteristics of microbial products in a partial nitrification sequencing batch reactor as a pretreatment for anaerobic ammonium oxidation. Chemosphere, 183, 212, 2017.

26. RONGSAYAMANONT C., LIMPIYAKORN T., LAW B., KHAN E. Relationship between respirometric activity and community of entrapped nitrifying bacteria: implications for partial nitrification. Enzyme \& Microbial Technology, 46 (3), 229, 2010.

27. FUX C., BOEHLER M., HUBER P., BRUNNER I., SIEGRIST H. Biological treatment of ammonium-rich wastewater by partial nitritation and subsequent anaerobic ammonium oxidation (anammox) in a pilot plant. Journal of Biotechnology, 99 (3), $295,2002$.

28. GONZALEZMARTINEZ A., RODRIGUEZSANCHEZ A., RIVADENEYRA M. A., RIVADENEYRA A., MARTINRAMOS D., VAHALA R., GONZALEZLOPEZ J. 16S rRNA gene-based characterization of bacteria potentially associated with phosphate and carbonate precipitation from a granular autotrophic nitrogen removal bioreactor. Applied Microbiology \& Biotechnology, 101 (2), 817, 2017.

29. ZHU D., MA Y., DING S., JIANG H., FANG J. Effects of melatonin on intestinal microbiota and oxidative stress in colitis mice. BioMed Research International, 2018 (6), $1,2018$.

30. XIAO Y., LIU X., MA L., LIANG Y., NIU J., GU Y., ZHANG X., HAO X., DONG W., SHE S., YIN H. Microbial communities from different subsystems in biological heap leaching system play different roles in iron and sulfur metabolisms. Applied Microbiology \& Biotechnology, 100(15), 6871, 2016.

31. XIAO J., GUO L., WANG S., LU Y. Comparative impact of cadmium on two phenanthrene-degrading bacteria isolated from cadmium and phenanthrene co-contaminated soil in China. Journal of Hazardous Materials, 174 (1), 818, 2010.
32. FIERER N., LAUBER C.L., RAMIREZ K.S., ZANEVELD J., BRADFORD M.A., KNIGHT R. Comparative metagenomic, phylogenetic and physiological analyses of soil microbial communities across nitrogen gradients. Isme Journal, 6(5), 1007, 2012.

33. LU S., LIU X., MA Z., LIU Q., WU Z., ZENG X., SHI X., GU Z. Vertical segregation and phylogenetic characterization of ammonia-oxidizing bacteria and archaea in the sediment of a freshwater aquaculture pond. Front Microbiol, 6 (326), 1539, 2016.

34. GAO J., LUO X., WU G., LI T., PENG Y. Abundance and diversity based on amoA genes of ammonia-oxidizing archaea and bacteria in ten wastewater treatment systems. Applied Microbiology \& Biotechnology, 98 (7), 3339, 2013.

35. FERNÁNDEZ-GÓMEZ B., RICHTER M., SCHÜLER M., PINHASSI J., ACINAS S. G., GONZÁLEZ J. M., PEDRÓS-ALIÓ C. Ecology of marine bacteroidetes: a comparative genomics approach. Isme Journal, 7 (5), 1026, 2013.

36. MENEZES A.B.D., PRENDERGASTMILLER M.T., POONPATANA P., FARRELL M., BISSETT A., MACDONALD L.M., TOSCAS P., RICHARDSON A.E., THRALL P.H. C/N ratio drives soil actinobacterial cellobiohydrolase gene diversity. Applied \& Environmental Microbiology, 81 (9), 3016, 2015.

37. HU M., WANG X., WEN X., XIA Y. Microbial community structures in different wastewater treatment plants as revealed by 454 -pyrosequencing analysis. Bioresource Technology, 117 (10), 72, 2012.

38. VENTER J.C., REMINGTON K., HEIDELBERG J.F., HALPERN A.L., RUSCH D., EISEN J.A. Environmental genome shotgun sequencing of the sargasso sea. Science, 304 (5667), 66, 2004.

39. LIMPIYAKORN T., SHINOHARA Y., KURISU F., YAGI O. Communities of ammonia-oxidizing bacteria in activated sludge of various sewage treatment plants in Tokyo. Fems Microbiology Ecology, 54 (2), 205, 2010.

40. TIETZ A., HORNEK R., LANGERGRABER G., KREUZINGER N., HABERL R. Diversity of ammonia oxidising bacteria in a vertical flow constructed wetland. Water Science \& Technology, 56 (3), 241, 2007.

41. WANG L., WANG X., YANG F., KONG M., PENG F., CHAO J., GAO Y., WU D., ZHU Y., ZHANG Y. Nitrogen removal performance and ammonia- and nitrite-oxidizing bacterial community analysis of a novel industrial wastebased biofilter. Chemical Engineering Journal, 299, 156, 2016. 
